\title{
TUGAS POKOK DAN FUNGSI (TUPOKSI) APOTEKER DI PUSKESMAS DALAM PELAYANAN OBAT MENURUT PERATURAN PERUNDANG-UNDANGAN
}

\author{
Putu Andika Dhananjaya ${ }^{1}$, Wiwin Mey Tjiang ${ }^{1}$, \\ Ni Nyoman Adhi Satvika Devi ${ }^{1}$, Ni Putu Ayu Inten Artania ${ }^{1}$, Ni Made Widi Astuti ${ }^{1}$ \\ ${ }^{1}$ Program Studi Profesi Apoteker, Fakultas Matematika dan Ilmu Pengetahuan Alam, \\ Universitas Udayana \\ Email: satvika.devi@student.unud.ac.id
}

\begin{abstract}
ABSTRAK
Puskesmas adalah sebuah fasilitas layanan kesehatan yang bertujuan untuk meningkatkan kesehatan masyarakat dimana didalamnya terkait dengan peran apoteker untuk memberikan pelayanan kefarmasian dengan baik. Pelayanan Kefarmasian merupakan pelayanan langsung yang bertanggung jawab terkait dengan sediaan farmasi agar dapat mencapai peningkatan kualitas dalam kehidupan pasien. Tugas pokok dan fungsi apoteker di puskesmas mencakup pelayanan kefarmasian mengenai pelayanan obat dan telah diatur dalam peraturan perundang-undangan. Pada pelaksanaannya belum sepenuhnya dijalankan dengan baik karena belum dianggap sebagai prioritas. Berbagai kasus penggunaan obat yang kurang sesuai bermunculan. Untuk itu perlu dilakukan kajian mengenai tupoksi apoteker di puskesmas berdasarkan peraturan perundang-undangan. Metode penulisan artikel ini berdasarkan studi pustaka melalui peraturan dan regulasi yang sah kemudian dikaitkan dengan kasus yang terjadi di masyarakat. Berbagai undang-undang dibuat pemerintah guna mengatur mengenai tanggung jawab seorang apoteker dalam menjalankan tugas dan fungsinya dalam hal-hal yang berkaitan dengan pelayanan kefarmasian seperti pelayanan obat sehingga diharapkan mampu meminimalisir kasus terkait obat yang terjadi di masyarakat. Tugas dan fungsi apoteker yang diatur dalam undang-undang mencakup pelayanan resep, konseling, dispensing, PTO, MESO, dan PIO.
\end{abstract}

Kata kunci: Apoteker, Puskesmas, Peraturan perundang-undangan, Tugas Pokok, Fungsi.

\begin{abstract}
Puskesmas is a health service facility that aims to improve public health, which is related to the role of pharmacists in providing good pharmaceutical services. Pharmaceutical services are direct services that are responsible for pharmaceutical preparations in order to achieve quality improvement in patient life. The main duties and functions of pharmacists in health centers include pharmaceutical services regarding drug services and have been regulated in laws and regulations. In practice, it is not yet fully implemented because it is not considered a priority. Various cases of inappropriate drug use have emerged. For this reason, it is necessary to carry out a study on the functions of pharmacists in health centers based on statutory regulations. The method of writing this article is based on literature study through legal rules and regulations which are then linked to cases that occur in society. Various laws have been made by the government to regulate the responsibilities of a pharmacist in carrying out their duties and functions in matters related to pharmaceutical services such as drug services so that they are expected to be able to minimize drug-related cases that occur in the community. The duties and functions of pharmacists which are regulated by law include prescription services, counseling, dispensing, PTO, MESO, and PIO.
\end{abstract}

Keywords: Pharmacist, Puskesmas, Legislation, Main Duties, Functions 


\section{PENDAHULUAN}

Puskesmas adalah suatu fasilitas pelayanan kesehatan tingkat pertama dalam pelayanan kesehatan masyarakat maupun perorangan dimana mengutamakan aspek preventif serta promotif, demi kualitas kesehatan sebaik-baiknya disuatu wilayah [1]. Tenaga kesehatan merupakan sarana penunjang keberhasilan dari tujuan penyelenggaraan kesehatan di Puskesmas. Salah satu tenaga kesehatan yang menunjang tercapainya kesehatan di Puskesmas yaitu pelayanan kefarmasian yang baik dan bermutu.

Pelayanan kefarmasian atau pharmaceutical care merupakan pelayanan yang secara langsung dan bertanggung jawab terhadap profesi apoteker dalam peningkatan kualitas hidup pasien [2]. Sehingga tenaga farmasi berkewajiban untuk meningkatkan kompetensi baik berupa pengetahuan, perilaku dan juga keterampilan agar siap berinteraksi langsung dengan pasien. Pelayanan kefarmasian umumnya meliputi pelayanan resep, Monitoring Efek Samping Obat (MESO), konseling, dispensing, Pemantauan Terapi Obat (PTO), dan Pelayanan Informasi Obat (PIO) [3]. Apoteker merupakan sebuah profesi yang diambil oleh sarjana farmasi yang telah lulus dalam pendidikan profesi Apotekernya serta telah mengucapkan sumpah jabatan akan profesi yang dijalani. Standar dari pelayanan kefarmasian di Puskesmas mencakup standar dari pengelolaan bahan medis habis beserta 63 sediaan farmasi serta menerapkan standar pelayanan farmasi klinis [4].

Pelayanan kefarmasian yang ada di Puskesmas awalnya masih sangat terbatas dan jarang, dikarenakan pelayanan kefarmasian merupakan minoritas yang masih belum dianggap penting. Namun, berbagai kasus bermunculan di Puskesmas mengenai kesalahan pemberian obat, kesalahan informasi obat, penjualan obat narkotika dan psikotropika, dan lain sebagainya. Hal inilah yang akhirnya menjadi pertimbangan keluarnya Undang-Undang yang mengatur pelayanan kefarmasian di Puskesmas dan mewajibkan setidaknya terdapat satu apoteker di Puskesmas untuk mendukung regulasi pelayanan kesehatan khususnya pelayanan kefarmasian di Puskesmas.

Penelitian ini memiliki tujuan untuk mengkaji lebih dalam mengenai tupoksi dari apoteker sebagai tenaga kefarmasian dalam upaya untuk mendukung kinerja Puskesmas untuk menyelenggarakan pelayanan kesehatan kepada masyarakat beserta mekanismenya yang telah diatur dalam peraturan perundangan.

\section{METODE PENELITIAN}

\section{Metode}

Penelitian yang dilakukan yaitu non-eksperimental dengan studi pustaka dan bersifat deskriptif, dengan tujuan mendeskripsikan secara sistematik, faktual, dan akurat mengenai regulasi sah yang tekait dengan tugas dan fungsi (tupoksi) apoteker dalam pelayanan obat di 
puskesmas. Pelayanan obat yang dimaksud yaitu pelayanan resep, konseling, dispensing, PTO, MESO, dan PIO.

\section{HASIL dan PEMBAHASAN}

Apoteker mempunyai tugas untuk menjamin barang atau jasa sampai kepada pasien dengan memperhatikan aturan perundang-undangan. Selain itu, Apoteker memiliki tugas yang penting dalam pelayanan obat yang mencakup pelayanan resep, konseling, dispensing, PTO, MESO, dan PIO. Seorang Apoteker haruslah memiliki surat izin yaitu SIPA agar dapat menjalankan tanggung jawabnya atau tugas pokok dan fungsinya (tupoksi) di Puskesmas.

Tugas pokok dan fungsi apoteker dalam aspek pelayanan obat telah dibahas dan disinggung dalam beberapa undang-undang yang telah disahkan oleh pemerintah. Salah satu aturan tersebut yaitu UU No. 32 Tahun 2004 yang membahas terkait otonomi daerah. Peraturan perundangundangan ini mengatur mengenai pemberian ijin untuk sarana kesehatan di suatu daerah salah satunya yaitu puskesmas yang menyediakan fasilitas kesehatan, ketersediaan obat serta perbelakan farmasi. Pada undangundang ini dijelaskan mengenai penyediaan dan pengelolaan obat, alat kesehatan, maupun vaksin baik itu bagi manusia maupun hewan. Regulasi ini bertujuan untuk menjaga dan memastikan agar penyelenggaraan kesehatan dapat berjalan dengan baik [5]. Pada undang-undang ini, tupoksi apoteker sangatlah penting mengingat

64 tugas yang dapat dilakukan apoteker yaitu pelayanan resep, konseling, dispensing, PTO, MESO, dan PIO. Hal ini dikarenakan apoteker yang mempunyai kompetensi untuk mengelola obat dari obat terdistribusi ke Puskesmas sampai diberikan kepada pasien.

Tenaga kefarmasian memiliki peranan penting dalam membangun dan mengembangkan bidang kesehatan dengan tanggung jawab yang secara langsung dalam memberikan pelayanan kefarmasian. Menurut PP No. 51 Tahun 2009 tentang Pekerjaan Kefarmasian, Pelayanan Kefarmasian merupakan sebuah pelayanan langsung yang bertanggung jawab kepada pasien untuk meningkatkan kehidupan pasien berkaitan dengan sediaan farmasi [3]. Pada undang-undang ini Apoteker dalam tupoksinya yakni melaksanakan pekerjaan kefarmasian dalam pelayanan sediaan farmasi juga dilakukan di Puskesmas. Regulasiregulasi ini menjelaskan bahwa seorang apoteker bertanggung jawab penuh terhadap kualitas obat yang akan digunakan oleh masyarakat dan cara penggunaan obat itu sendiri agar dapat menghindari kasus kesalahan penggunaan obat dimasyarakat.

Penempatan apoteker di puskesmas dianggap belum menjadi prioritas yang memiliki peranan penting untuk mengurangi angka kematian ibu dan/atau angka kematian bayi [6]. Pengawasan dan monitoring terhadap obat menjadi tidak terawasi dengan baik akibat tidak adanya apoteker di puskesmas. Kasus-kasus 
berkaitan dengan keracunan bahkan kematian dilaporkan akibat pemberian obat kadaluwarsa. Hal tersebut menandakan bahwa perencanaan obat di puskesmas tidaklah berjalan dengan optimal. Selain itu juga, kasus lain yang terjadi adalah pasien tidak mendapatkan komunikasi, informasi, dan edukasi (KIE) mengenai obat yang dikonsumsinya [7]. Undang Undang No. 36 Tahun 2009 dalam Pasal 8 menunjukkan setiap orang memiliki hak dalam memeroleh informasi dan pengetahuan mengenai segala tindakan dan segala bentuk pengobatan yang telah diberikan maupun yang akan diterimanya [8]. Hal ini sejalan dengan hak yang dimiliki oleh konsumen atas keselamatan, keamanan, dan kenyamanan dalam mengonsumsi barang (obat) sebagaimana diatur dalam Undang-Undang No. 8 Tahun 1999 terkait perlindungan konsumen [9].

Menurut Pasal 16 pada PP No. 72 tahun 1998 yang membahas mengenai pengamanan sediaan farmasi dan alat kesehatan menyebutkan bahwa sediaan farmasi diserahkan untuk dapat dipergunakan dalam bidang pelayanan kesehatan atau untuk digunakan dalam ilmu pengetahuan [10]. Penyerahan sediaan-sediaan farmasi dilakukan berdasarkan resep dokter atau tanpa resep dokter. Peran apoteker dalam penyerahan resep kepada pasien di puskesmas dilakukan berdasarkan peraturan tersebut, hendaknya seorang apoteker memeriksa kembali resep obat sebelum memberikan obat kepada 65 pasien. Salah satu kasus terjadi ditahun 2019 yang diberitakan dalam surat kabar Jawa Pos bahwa terdapat resep palsu guna dapat membeli obat keras yang dibuat oleh oknum-oknum tidak bertanggung jawab [11]. Kasus yang sama diberitakan kembali oleh BPOM pada 15 Mei 2020 dalam surat kabar Galamedianews.com mengenai peredaran dan pembelian obat keras tanpa resep dokter. Obat-obatan ini banyak dijual bebas dan dapat ditemukan di toko online [12]. Jelas bahwa hal ini tidak sesuai dengan peraturan perundang-undangan yang berlaku, dimana obat-obatan ini secara tegas diberikan oleh apoteker atas adanya resep dari dokter. Tugas dan fungsi sebagai seorang apoteker secara tegas dan jelas untuk meninjau kembali resep yang dibawa oleh pasien untuk mengurangi kecurangan pembelian obat keras tanpa resep dokter. Pelayanan informasi mengenai obat sangat penting agar kasus pembelian obat terlarang dan obat keras dapat dikurangi, karena adanya kesadaran masyarakat tentang pentingnya menjaga kesehatan diri sendiri dan orang lain. Hal ini dengan sangat jelas tercantum pada PP No. 72 tahun 1998 pada pasal 26 mengenai penandaan serta informasi terkait dengan sediaan farmasi dilakukan sebagai bentuk perlindungan kepada masyarakat dalam hal penerimaan informasi yang tidak lengkap dan tidak subjektif serta menyesatkan [10].

UU No. 35 tahun 2009 terkait narkotika dalam pasal 4, narkotika diserahkan atau diberikan untuk kepentingan dalam melakukan

Putu Andika Dhananjaya, Wiwin Mey Tjiang, Ni Nyoman Adhi Satvika Devi, Ni Putu Ayu Inten Artania, Ni Made Widi Astuti Program Studi Profesi Apoteker, Fakultas Matematika dan Ilmu Pengetahuan Alam, Universitas Udayana 
pelayanan kesehatan dan/atau untuk mengembangkan ilmu pengetahuan serta teknologi. Penyaluran narkotika telah diatur dalam pasal 39 yang menyatakan bahwa narkotika hanya boleh didistribusikan oleh pedagang besar farmasi atau biasa disebut PBF, industri farmasi, dan sarana penyimpanan sediaan farmasi milik pemerintah sesuai ketentuan yang berlaku [13]. Selain narkotika, obat psikotropika juga tidak boleh beredar di masyarakat secara bebas. Hal tersebut sudah dimuat dalam UU No. 5 tahun 1997 berkaitan dengan psikotropika. Pasal 12 berisi mengenai penyaluran psikotropika yang hanya boleh dilaksanakan oleh pedagang besar farmasi atau disingkat dengan PBF, pabrik obat, serta sarana penyimpanan sediaan farmasi milik pemerintah [14]. Banyak terjadi kasus peredaran narkotika, psikotropika, dan obat keras yang dijual secara bebas dimasyarakat tanpa sepengetahuan apoteker maupun tanpa adanya resep dokter. Kasus yang sering terjadi yaitu penjualan bebas obat Amoxicilin yang telah diberitakan dalam beberapa surat kabar, salah satunya diberitakan pada 19 Juni 2019 dalam surat kabar Pasundanekspres.co [15]. Pada tanggal 20 Februari 2020 diberitakan dalam surat kabar Detik Health mengenai rawannya penyalahgunaan obat, khsusnya obat keras yang dijual secara bebas di beberapa toko online tanpa adanya pengawasan dari apotek dan resep dari dokter [16]. Obatobatan seperti tramadol, rhexiphenydyl, hexymer, dan obatobat keras daftar $G$ juga menjadi 66 incaran para oknum-oknum yang tidak bertanggung jawab untuk dijual secara bebas. Hal ini dilaporkan pada 6 Mei 2020 dalam surat kabar kompas.com, dimana obat-obat ini biasa disalahgunakan oleh masyarakat untuk mendapatkan ketenangan dan kepuasan [17]. Selain dari pada itu, pada 24 Maret 2020 dalam surat kabar detik finance kembali diberitakan mengenai maraknya penjualan obat klorokuin yang diklaim mampu menyebuhkan pasien yang tekena virus Covid-19. Namun pihak kimia farma dengan tegas menekankan bahwa pihaknya tidak ada menjual obat tersebut seperti yang beredar di toko online [18]. Meskipun kasus ini melibatkan apotek, namun tidak menutup kemungkinan agar apoteker yang berada di Puskesmas agar dengan cepat dan tanggap dalam memberikan informasi mengenai obat-obat yang beredar dipasaran secara online. Informasi yang dapat diberikan berupa efek samping, kebenaran klaim khasiat obat dan penggunaan dari obat itu sendiri yang seharusnya menggunakan resep dari dokter. Jika hal ini masih terus terjadi di masyarakat, maka tidak menutup kemungkinan akan adanya ketergantungan dan terjadinya resistensi obat khususnya antibiotik. Adanya peran apoteker dalam hal ini sangat penting untuk meninjau kembali mengenai pentingnya pengelolaan dan pemberian informasi terkait obat yang beredar di masyarakat secara online maupun dalam pembelian secara illegal. Pemberian informasi dapat berupa penjelasan dan pemahaman mengenai

Putu Andika Dhananjaya, Wiwin Mey Tjiang, Ni Nyoman Adhi Satvika Devi, Ni Putu Ayu Inten Artania, Ni Made Widi Astuti Program Studi Profesi Apoteker, Fakultas Matematika dan Ilmu Pengetahuan Alam, Universitas Udayana 
efek samping yang ditimbulkan dari penggunaan obat-obat keras, narkotika serta obat golongan psikotropika. Oleh sebab itu, erat kaitannya dengan tugas pokok dan fungsi apoteker dalam melakukan pengecekan dan peninjauan kembali resep yang diberikan.

Berdasarkan PMK No. 3 Tahun 2015, berkaitan dengan obat-obatan narkotika dan/atau psikotropika beserta prekursor farmasi yang merupakan golongan obat keras di puskesmas kemudian hanya boleh diserahkan ke pasien sesuai dengan resep dokter [19]. Peran apoteker dalam melaksanakan kewajiban atau tugas pokok dan fungsinya dalam hal ini tentu sangat mempengaruhi kepatuhan masyarakat terhadap penggunaan golongan-golongan tersebut sehingga kasus penyalahgunaan juga dapat ditekan. Pelaksanaan SOP yang sesuai oleh apoteker dapat menjamin kesehatan, keamanan, dan kenyamanan dari pasien yang akan terus meningkat. Hal ini yang kemudian yang akan membantu pasien untuk patuh dan peduli terhadap penggunaan obat dan kesehatannya. Sehingga angka kasus yang terjadi di masyarakat seperti obat kadaluwarsa dapat ditekan. Apoteker yang dalam menjalankan peranannya tidak sesuai dengan peraturan perundangan akan diberikan sanksi tegas. Sanksi yang diberikan sesuai dengan ketentuan atau regulasi yang tercantum dalam peraturan perundangundangan.

Tinjauan peran Apoteker berkaitan dengan pelayanan kesehatan khususnya puskesmas menjadikan dasar dibentuknya Permenkes No. 74 Tahun 2016. Peraturan menteri kesehatan ini menunjukkan peran penting yang dimiliki oleh apoteker sehingga diharapkan mampu meminimalisir kasus-kasus yang terjadi terutama dalam hal pelayanan obat. Bab III Permenkes No. 74 Tahun 2016 menjelaskan terkait pelaksanaan pelayanan farmasi klinis dimana merupakan salah satu tanggung jawab pelayanan kefarmasian secara langsung terhadap pasien yang berkaitan dengan penggunaan obat serta bahan medis habis pakai yang memiliki maksud dan tujuan agar tercapainya peningkatan standar mutu dalam kehidupan seorang ataupun segolongan pasien. Permenkes No. 74 Tahun 2016 ini menyebutkan tugas dan tanggung jawab apoteker berkaitan dengan meningkatkan kualitas atau mutu hidup pasien mulai dari pengkajian resep, pelayanan resep, PIO, MESO, dispensing, konseling, PTO serta evaluasi penggunaan obat. Dengan demikian, diterbitkannya permenkes ini diharapkan mampu memperbaiki serta mengurangi angka kasus terkait perencanaan obat di puskesmas [4]. Tugas dan fungsi apoteker selaku pemberi pelayanan kepada masyarakat harus mampu memberikan konseling dan memberikan informasi terkait efek samping obat, bahaya obat, dan kesadaran masyarakat untuk tidak membeli obat terlarang maupun prekursornya agar mengurangi terjadinya kasus kematian dan

67 
kecelakaan akibat kesalahan penggunaan obat.

Sekarang ini, telah disediakan jaminan perlindungan kesehatan yang diberikan kepada masyarakat untuk memperoleh manfaat dalam hal kesehatan dan perlindungan agar dapat memenuhi kebutuhan dasar dalam kesehatan yang diberikan kepada setiap orang yang iuranya dibayarkan oleh pemerintah. Pelayanan kesehatan yang diselenggarakan oleh pemerintah kepada peserta penerima JKN terdiri atas fasilitas kesehatan tingkat pertama serta fasilitas kesehatan rujukan tingkat lanjutan. Salah satu fasilitas kesehatan tingkat pertama yang menyediakan fasilitas JKN ialah puskesmas [20]. Maka dari itu apoteker, sebagai salah satu tenaga kesehatan di puskesmas juga harus berperan dalam pelaksanaan program JKN. Peranan apoteker dalam menjamin terlaksananya JKN secara baik yaitu dengan menjamin ketersediaan obat dan alat kesehatan, pemerataan, keterjangkauan obat, menjamin khasiat, mutu, dan keamanan obat yang beredar serta memberikan perlindungan kepada masyarakat dari penggunaan yang keliru atau tidak sesuai dan penyalahgunaan obat. Selain itu juga, apoteker berperan penting dalam pelayanan obat dalam memberikan konseling obat kepada pasien sehingga penggunaan obat yang baik dan benar dapat terlaksana secara maksimal. Serta Apoteker bertanggung jawab untuk menjalankan SOP yang ada seperti pelayanan obat meliputi skrining resep, penyiapan resep 68 racikan, pelayanan informasi obat, hingga konseling [21].

\section{KESIMPULAN}

Adanya berbagai kasus yang terjadi di masyarakat bersumber pada pelayanan di Puskesmas terlebih dalam hal pelayanan obat menjadikan apoteker adalah elemen yang penting untuk ada di Puskesmas. Keberadaan apoteker dalam hal ini menjalankan tugas pokok dan fungsinya dalam hal pharmaceutical care termasuk di dalamnya mencakup hal penting yakni pelayanan kefarmasian. Apoteker memiliki tanggung jawab atas segala bentuk yang berkaitan dengan pelayanan kefarmasian sehingga diharapkan mampu meminimalisir kasus terkait obat yang terjadi di masyarakat.

Pentingnya peranan serta tugas dan fungsi (tupoksi) seorang Apoteker di Puskemas mengenai pengelolaan obat dan pelayanan pemberian informasi terkait obat yang beredar di masyarakat baik itu secara online maupun secara illegal akan dapat mengurangi kasus penyalahgunaan obat dan pemalsuan resep.

\section{UCAPAN TERIMA KASIH}

Terima kasih kami sampaikan terhadap pihak-pihak yang telah mendukung dan membantu yaitu program studi profesi apoteker.

\section{DAFTAR PUSTAKA}

[1] Permenkes RI. 2014. Peraturan Menteri Kesehatan Republik Indonesia Nomor 75 Tahun 2014 tentang Pusat Kesehatan

Putu Andika Dhananjaya, Wiwin Mey Tjiang, Ni Nyoman Adhi Satvika Devi, Ni Putu Ayu Inten Artania, Ni Made Widi Astuti Program Studi Profesi Apoteker, Fakultas Matematika dan Ilmu Pengetahuan Alam, Universitas Udayana 
Masyarakat. Jakarta: Meteri Kesehatan Republik Indonesia.

[2] Hartini, SY. 2009. Relevansi Peraturan dalam Mendukung Praktek Profesi Apoteker di Apotek. Majalah Ilmu Kefarmasian, VI (2):97-106.

[3] PP RI. 2009. PP RI. 2009. Peraturan Pemerintah Republik Indonesia Nomor 51 Tahun 2009 tentang Pekerjaan Kefarmasian. Jakarta: Presiden Republik Indonesia.

[4] Permenkes RI. 2016. Peraturan Menteri Kesehatan Republik Indonesia Republik Indonesia Nomor 74 Tahun 2016 tentang Standar Pelayanan Kefarmasian di Puskesmas. Jakarta: Menteri Kesehatan Republik Indonesia.

[5] Depkes RI. 2004. Undang Undang No. 32 Tahun 2004 tentang Otonomi Daerah. Jakarta: Departemen Kesehatan Republik Indonesia.

[6] Supardi, S., A. L. Susyanti, Raharni, dan M J. Herman. 2012. Kebijakan Penempatan Apoteker Di Puskesmas. Buletin Penelitian Sistem Kesehatan. 15(2):133-142.

[7] Triana, M., C. Suryawati dan A. Sriyatmi. 2014. Evaluasi Perencanaan Obat Pelayanan Kesehatan Dasar (PKD) di Gudang Farmasi Kabupaten Gunung Mas Provinsi Kalimantan Tengah. Jurnal Manajemen Kesehatan Indonesia, 02(01):4451.

[8] Depkes RI. 2009. Undang Undang No. 36 Tahun 2009 tentang
Kesehatan. Jakarta: Departemen Kesehatan Republik Indonesia.

[9] Depkes RI. 1999. Undang-Undang Republik Indonesia No. 8 Tahun 1999 tentang Perlindungan Konsumen. Jakarta: Departemen Kesehatan Republik Indonesia.

[10] PP RI. 1998. Peraturan Pemerintah Nomor 72 tahun 1998 tentang Pengamanan Sediaan Farmasi Dan Alat Kesehatan. Jakarta: Menteri Kesehatan Republik Indonesia.

[11] Perdana. 2019. Awas Resep Palsu untuk Beli Obat Keras. Diakses pada 04 Oktober 2020 pukul 11.32 WITA, https://radarsolo.jawapos.com/rea $\mathrm{d} / 2019 / 09 / 06 / 154470 /$ awas-reseppalsu-untuk-beli-obat-keras.

[12] Galamedianews. 2020. BPOM: Masih Banyak Toko Daring Menjual Obat Keras Tanpa Resep Dokter. Diakses pada 05 Oktober 2020 pukul 10.22 WITA, https://galamedia.pikiranrakyat.com/news/pr35562368/bpom-masih-banyaktoko-daring-menjual-obat-kerastanpa-resep-dokter.

[13] Depkes RI. 2009. Undang Undang No. 35 Tahun 2009 tentang Narkotika. Jakarta: Departemen Kesehatan Republik Indonesia.

[14] Depkes RI. 1997. Undang Undang No. 5 Tahun 1997 tentang Psikotropika. Jakarta: Departemen Kesehatan Republik Indonesia.

[15] Redaksi. 2019. Farmasi Dilema: Obat Keras Dijual Secara Bebas. Diakses pada 04 Oktober 2020 pukul $11.25 \quad$ WITA,

Putu Andika Dhananjaya, Wiwin Mey Tjiang, Ni Nyoman Adhi Satvika Devi, Ni Putu Ayu Inten Artania, Ni Made Widi Astuti Program Studi Profesi Apoteker, Fakultas Matematika dan Ilmu Pengetahuan Alam, Universitas Udayana 
https://www.pasundanekspres.co/ opini/farmasi-dilema-obat-kerasdijual-secara-bebas/.

[16] Detik Health. 2020. Farmasi Dilema: Obat Keras Dijual Secara Bebas. Diakses pada 5 Oktober 2020 pukul 12.02 WITA, https://health.detik.com/beritadetikhealth/d-4906498/rawanpenyalahgunaan-obat-obat-kerasmasih-banyak-dijual-bebas.

[17] Kompas. 2020. Polisi Selidiki Peredaran Obat Psikotropika yang Dijual Bebas di ECommerce. Diakses pada 04 Oktober 2020 pukul 11.29 WITA, https://megapolitan.kompas.com/r ead/2020/05/10/14520341/polisiselidiki-peredaran-obatpsikotropika-yang-dijual-bebasdi-e?page $=$ all.

[18] Detik finance. 2020. 'Obat' Corona Chloroquine Tak Dijual di Apotek Kimia Farma. Diakses pada 05 Oktober 2020 pukul 12.33 WITA, https://finance.detik.com/beritaekonomi-bisnis/d-4951002/obatcorona-chloroquine-tak-dijual-diapotek-kimia-farma.

[19] Permenkes RI. 2015. Peraturan Menteri Kesehatan Republik Indonesia Nomor 3 Tahun 2015 tentang Obat-Obatan Narkotika Dan/Atau Psikotropika Dan Prekursor Farmasi Golongan Obat Keras. Jakarta: Menteri Kesehatan Republik Indonesia.

[20] PP RI. 2018. Peraturan Presiden Republik Indonesia Nomor 82 Tahun 2018 tentang Jaminan
Kesehatan. Jakarta: Presiden Republik Republik Indonesia.

[21] Depkes RI. 2006. Pedoman Pelayanan Kefarmasian di Puskesmas. Jakarta: Departemen Kesehatan Republik Indonesia. 